\title{
Forest Resources of Cross River State: Their Potentials, Threats and Mitigation Measures
}

\author{
Philip fon $(\mathrm{Jr})^{1}$, Oluyemi Ayorinde Akintoye ${ }^{2}$, Tokunbo Olorundami ${ }^{2}$, \\ Charles Ojong Nkpena ${ }^{3}$ Sammy Uka Ukata ${ }^{2}$, Edet Ubong Harrison ${ }^{2}$ \\ ${ }^{1}$ Cross River State Ministry of Agriculture, Calabar, Cross River State, Nigeria \\ ${ }^{2}$ Department of Geography and Environmental Science University of Calabar, Calabar, Cross River State, \\ Nigeria \\ ${ }^{3}$ Department of Research and Planning Cross River State Tourism Bureau Calabar-Cross Rive State
}

\begin{abstract}
The distinctive species richness of the Tropical Rain Forest (TRFs) gives it a very high ecological importance. The TRFs also have economic and functional importance, which are of international and local dimensions. Cross River State (CRS) presently has about 40 percent of the remaining threatened TRFs of Nigeria. These forests harbor the largest remnant of comparably unlogged TRFs in the country. The areas covered by the forests are also homes to several rural and indigenous people. At least 75 percent of the total populations of the state live in rural areas. Cross River state is also renowned, worldwide for its ecotourism potentials. The ecotourism industry depends largely on the TRFs, in which species endemic to CRS can be found. Given the present threats posed by several old and emerging factors, this document is fashioned to present a description and compendium of the various forest resources of Cross River state of Nigeria. The major areas of focus include highlights of the forest types. Also considered were economic plants, including timber and nontimber forest products (NTFPs) as well as animal species found in the forests of Cross River state. The article also identifies the various threats to the Forests of Cross River State. In order to solve identified problems, recommendations proffered include need for provision of adequate funds by government, individuals and nongovernmental organizations aimed at better forest management ; employment of more and better trained forestry personnel; and more efforts on planting of indigenous species to boost biodiversity was advocated.

Key Words. Forest Resources. Mitigation Measures. Non- Timber Forest Products. Biodiversity.
\end{abstract}

\section{Introduction}

The term "Forest" may be defined as any vegetation dominated by trees while trees, are plants that can grow to heights above 10 meters and have woody stems (Nwoboshi,1982). The forests influence the economy as well as environmental stability of an area (Cross River State Forestry Strategy, 1994). For instance, the forests provide medicines, fuelwood, building materials, farmland, protein (bush meat and fish), food etc. Over the last decades, Cross River State has lost about 19\% of its tropical high forests due to inadequate funding of the Forestry Department, increase in population and immigration as well as plantation establishment (CRS, Forestry Strategy). The population of Cross River State is about 2.89 million (2006 census) with a land mass of about 21, $265 \mathrm{~km}^{2}$. There are about 2000 communities in the rural areas of the state which harbors $70 \%$ of the population. The main occupations of Cross Riverians include farming, hunting, extraction and gathering of timber and nontimber forest products. At present, the state has about $31 \%$ of the total remaining tropical high forests in Nigeria. These forests are made up of the Forest Reserves, Community forests and Cross River National Park forests.

However there are great concern, worldwide about the trend in the existing rate of utilization of forest resources, as well as the consequences on the physical and socio-economic environment (Bisong and Mfon, 2008 , Akintoye et al. 2013 and Okpiliya et al , 2013 and Ukata, et al (2013). Ukata et al (2013) for instance carried out an appraisal of primate conservation programme by Pandrillus (Non-Governmental Oranization) in Afi Mountain Sanctuary, Buanchor, Boki Local Government Area , Cross River State, Nigeria. Cross River is rapidly developing its ecotourism potentials , and its internationally being acknowledged as a leading tourism destination in Nigeria. The ability to balance, utilization and preservation of species, especially those endemic to Cross River state, presents a sound foundation for environmental sustainability as well as great money spinning potential, in the not too distant future.

This article is thus fashioned to provide an insight into the characteristics of the forests in Cross River State. It is also expected that it will highlight a few forest resources utilization issues, which could be problematic .It is expected that, information provided by this literature, will be of high value in forest management and planning exercises, locally and internationally.

For the purpose of management, the forest land of Cross River State may be classified into three (3) types namely; 
i. Mangrove and swamp Forests which can be found in Calabar Municipality, Calabar South, Odukpani, Akpabuyo,Abi and Bakassi Local Government Areas of the State.

ii. Tropical Rain Forest which exists in Akamkpa, Biase, Yakurr, Obubra, Ikom, Etung and Boki Local Government areas.

iii. The Savannah Forest which could be found in Obudu, Obanliku, Yala, Ogoja and Bekwarra Local Government Areas.

\section{Features of the forest estates of cross river state}

The Forest resources of the state cover's six ecological zones namely (Dunn et al,

i. Mangrove forests with an area of

$480 \mathrm{Km}^{2}$

ii. Swamp forest with an area of

$520 \mathrm{Km}^{2}$

iii. Tropical High Forests including the National

Park with an area of

iv. Plantations with an area of

$7,290 \mathrm{Km}^{2}$

v. Other forests with an area of

$460 \mathrm{Km}^{2}$

vi. Other land uses have an area of

$12,299 \mathrm{Km}^{2}$

The volume of timber from Tropical High Forest (THFs) in Cross River state excluding the Cross Rtver National Park is about 67 million $\mathrm{M}^{3}$ (Dunn et al, 1994) while the volume from forestry plantations of various species is about 8.58 million $\mathrm{M}^{3}$ (Ettah and Ogar, 1994). Over 700 different non- timber forest products have been identified in Cross River state of which over 430 species are harvested in the state. For instance, there are over 50 million matured large stems and 30 million small stems of rattan canes while there are over 2.5 million stands of bush mango (Dunn et al, 1994).

\section{Some Economic Plants and Animals Species Found in the Forests of Cross River State.}

There are many and varied and include the following (Mfon,1997, Alexander and Effa (1994).

1.1 Medicinal plants \{vernacular-efik (*) \& common names (**) in bracket\}:

i. Drypetes flouribonda (Drypetes)** - Bark is used for the treatment of heart diseases.

ii. Enantia chlorenta - Bark is used for the treatment of malaria fever

iii. Morinda lucida (Mbubuk ikon)* - Root and bark are also used for the treatment of malaria fever.

iv. Alstonic boonei (Ukpo)* - Bark is used for the treatment of sexually transmitted diseases.

v. Cnestis ferrugina - The root is used as an aphrodisiac.

vi. Schomatorphytum magnificum- This is used in the production of anti snake venom.

vii. Fagara species (ukek $)^{*}$ - The bark of this plant suppresses sickle cell anemia.

viii. Milicia excelsa (Iroko)** - Has anti-fungal action

ix. Garcinia mannii (Chewing sick)** (okok)* - Has antibacterial property therefore prevents tooth decay.

x. Carica papaya (Pawpaw)** - Used in the treatment of bile problems, swellings and malaria fever.

xi. Nauclea Latifolia - Leave is used to remedy stomach infections

xii. Elaes guineensis (palm tree)** (Eyop)* - Oil from the fruit is used in the treatment of coughs while kernel oil is used in the preparation of antidote against poisons. Juvenile epilepsy, convulsions and skin diseases are treated with preparations from the palm tree.

xiii. Bryophyllum pinnatum - The leaves are used to cure respiratory diseases such as asthma, whooping cough and bronchial problems.

xiv. Harungana madagascariencis (Oton)* - Leaves are used to cure skin infections while latex is used to heal fresh wounds.

xv. Sida acuta - Used as laxative for pregnant women

xvi. Python sebae and python regius _(Boa)**(Asabo)* - Oil is used in the treatment of boils, eczema, scabies, massaging of fractured or sprained limbs, diarrhea, dysentery and other intestinal infections.

xvii. Lizards (Ekpok)*- Used in the treatment of respiratory diseases.

xviii. Monkeys (Ebok)* - Skin used in the treatment of whooping cough.

\subsection{Vegetables, Friut, Beaverages (Vernacular and Common names in bracket)}

i. Gnetum africanum (Afang)* $\quad$ - $\quad$ Vegetable

ii. Labianthera africanum - $\quad$ Vegetable

iii. Hensia spp. (Atama)* - Vegetable

iv. Pipers guinenses (Hot leaf) $* *($ Etinkeni) $*$ - Spice/Vegetable 
v. Tomatoccus spp_(Nkong)* (wrapping leaf)** -Wrapping leaves

vi. Gondroema spp (Utasi)* $\quad-\quad$ Vegetable

vii. Mitragyna spp (owen)** - W Wrapping leaves

viii. Pycnanthus anglolenses (abakang)* - Edible fruits

ix. Elaes guinenses (palm tree)**(Eyop)* - Edible fruits, oil and wine, broom

X Raphia hookerii (Raffia palm)**(Ukot)*- Wine and building mats

xi. Raphia vinifera (Raffle palm)** (Ukot)*_ $\quad$ Wine, and building mats

xii. Nypa palm $\quad$ - $\quad$ Sugar, building mats and ornaments

xiii. Cocus nucifera (Coco nut)**(Isip Mbakara)*-Beverage, fruit and building mat.

xiv. Pterocarpus santalinoides (Mkpa)* - Vegetable

xv. Bombax spp and ceiba spp (silk cotton tree)** (Ukim)* - vegetable

xvi. Butyrospermum paradorum (shear butter) ${ }^{* *}$ - Nuts-produce oil

xvii. Coula edulis (Ekom)* ${ }^{*} \quad$ Edible fruits.

\subsubsection{Timber Producing Species \{Vernacular(Efik) and Common Names In Bracket\}}

These are very many and most popular species include;

i. Baillonella toxisperma_(mimusops)**

ii. Brachystegia spp (achi)**

iii. Entandrophragma spp_(Mahogany)**

iv. Khaya spp (Mahogany)**

v. Lovoa trichiloides (Cedar)**

vi. Milicia excelsa (Iroko)**

vii. Nauclea diderrichii (Opepe)**

viii. Piptadiniastrum afrianum (Ukong)*

ix. Poga oleosa (Enoi)*

x. Ptercarpus osun (cam wood)** (Ukpa)*

xi. Terminalia ivorensis (Black Afara)**

xii. Tripoohiton sclero xyon (obeche)**

xiii. Alstonia spp (Ukpo)*

xiv. Mitragyna spp (Abura)**

xv. Oxystigma spp (Ntufiak)*

xvi. Stauditia stipitata (Iyip okoyo)*)

xvii. Lophira spp (Eki/Ironwood)**

xviii. Chysophyllum spp (Udari)*

xix. Uapaca guineensis (Mkpenek)*

\subsubsection{Species for Poles ( Vernacular and Common Names in Bracket)}

i. Harungana madagascarienses (Oton)*

ii. Xylopia spp (Atarabang)*

iii. Nauclea spp (Opepe)**

iv. Rhizophora spp (Red mangrove)**

v. Avecinia spp (White Mangrove)**

vi. Bambusa vulgaris (Indian bamboo)**

\subsubsection{Plantation Species (Common Names in Bracket)}

i. Tectona grandis (Teak)

ii. Gmelina arborea (Gmelina)

iii. Lovoa trichilioides (cedar)

iv. Cedrella spp (Mahogany)

v. Tripolochiton sleroxylon (Obeche)

\subsection{Animals}

There are also many and varied and include the following:

\subsubsection{Aquatic Animals( Common Names in Bracket)}

i. Several species of fish in the Mangrove and Swamp Forests. Common examples include:

a. Tilapia sillii (Tilapia)

b. Chrysichthys spp (catfish)

c. Ethmals fimbriate (Bonga fish) 

d. Periophthalmus spp (Mud skipper)
ii. Tympanotonus fuscatus (Periwinkle)
iii. Grypheae gasor (Oyster)
iv. Anadera spp (Clam)
v. Penaeus notalis (Crayfish)S

\subsubsection{Reptiles}

i. Several species of snakes-Order :Ophidia

ii. Alligators, Crocodiles, Monitor lizards Order: Crocodilia

iii. Tortoise and Turtles :Order Testudinata

\subsubsection{Primates}

i. Pottos - Artocebus spp

ii. Monkeys-fam: cercopithecidae

iii. Baboons - Papio anubis

iv. Drills - Papio leucophaeus

v. Chimpanzees - Pan troglodytes

vi. Gorillas - Gorrila gorilla

\subsubsection{Rodents}

i. Several species of rats-Order:Rodentia

ii. Squirells - Epixerus ebi

iii. Porcupine - Atherurus Africana

\subsubsection{Large mammals.}

$\begin{array}{lll}\text { i. } & \text { Manatee - } & \text { Trichochus senegelensis } \\ \text { ii. Antelope - } & \text { family: Bovidae } \\ \text { iii. Hippopotamus- } & \text { Hyppoppotamus amphibius } \\ \text { iv. Bush Pig - } & \text { Hylochoerus meinertshbani } \\ \text { v. Elephants - } & \text { Loxodonta africana } \\ \text { vi. Buffalo } \quad- & \text { Syncerus caffer } \\ \text { vii Lions } & - & \text { Panthera leo } \\ \text { viii Leopard- } & & \text { Panthera pardus }\end{array}$

\subsubsection{Birds}

There are many and varied include the following:

$\begin{array}{lll}\text { i. } \text { Secretary Bird } & - & \text { Sagittarius serpenarious } \\ \text { ii. African spoon bill } & - & \text { Platelea alba } \\ \text { iii. Horn bill } & - & \text { Bucorvus spp } \\ \text { iv. Heroes and egrets } & - & \text { Family Ardeida } \\ \text { v. Pelicans } & - & \text { Family: pelecanidae } \\ \text { vi. Storks } & - & \text { Family; cioniidae } \\ \text { vii. Vultures } & - & \text { Family: Agypiidae } \\ \text { viii. Water foul } & - & \text { Family: Anas spora } \\ \text { x. Parrots } & - & \text { Family: Columbidae }\end{array}$

xi. Francolins, Quails and Guinea fowls - family phasianidae

It is worth mentioning that the forest of Boki local Government Area in Cross River State serves as a sanctuary for swallow birds from Europe. These birds roost in this forest during the European winter and fly back to Europe after the winter.

\section{Threats to the Forests of Cross River State}

These threats may be referred to as agents of deforestation. Deforestation is a term used to denote the removal of plants mainly trees without replanting and where there is replanting, the number/area planted is usually less than what is removed.

Agents of deforestation may be divided into three (3):

(Carty, 1992; NEST, 1991; Taylor, 1983: Came et al 1980; Akachukwu, 2007; FAO, 2004; UNEP - WCMC, 2004) 


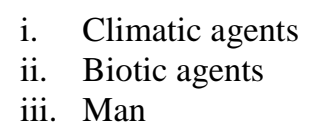

\subsection{Climatic Agents}

i. Sunlight - Is very essential during photosynthesis, but high intensity of sunlight has been known to kill plants, especially the young ones.

ii. Water - This is equally imperative for the growth of plants such that, where there is drought, most plants die. Also, excessive presence of water such as during floods, kill, some plants.

iii. Wind - Although wind is essential in the pollination and dispersal of seeds of some plants, it is sometimes associated with defoliation (removal of leaves), breaking of tree branches as well as uprooting of trees.

\subsection{Biotic Agents}

i. Non Green Plants: These include fungi, bacteria and viruses which attack all part of trees and at times killing the entire plant.

ii. Animals - This include insects, and other animals such as rodents, primates, antelopes and elephants which feed on plants. In some cases, a lot of damage is done to the forest leading to erosion.

\subsection{Man}

Of all the agents of deforestation, man is the most destructive. In fact, without the interference of man, the forests would have been least disturbed. The effects of man on the forests include the following;

i. Agriculture: Crop farming and livestock

ii. Lumbering

iii. Urbanization and Industrialization

iv. Fire

v. Fuel wood collection

4.3.1 Agriculture: During site preparation for planting, under brushing and felling are carried out leading to deforestation. The traditional method of shifting cultivation has led to the permanent destruction of the rain forest (Came et al, 1980). In some cases the stocking rate of trees is reduced leading to derived savannah. In slopes, floods may ravage lowlands and silts will clog dams' irrigation canals. Some weeds have been introduced eg Eupatorium odoratum from South-East Asia to West Africa (NEST, 1991).

Grazing by livestock is associated with change in vegetation from Guinea Savannah to Derived Savannah since animals eat young trees especially in the dry season which there is little grass to sustain them.

\subsubsection{Lumbering}

At present, sawn timber is indispensable in construction. Therefore many trees are felled and sawn without replanting measures leading to deforestation.

\subsubsection{Urbanization And Industralization}

Construction of infrastructures such as ports, schools, railways, airports and highways has lead to the destruction of the forest. Over population has led to a lot of infrastructure being constructed thereby threatening the forest.

4.3.4 Fire: Man is the major cause of most fire outbreaks, although lightening and volcanism are also associated with fire. Most of the rain forest species are not resistant to fire like the Savannah species. Fire has been known to devastate the forests. Man uses fire for farming, hunting and at times, the fire is out of control causing serious problems.

4.3.5 Fuelwood: In most developing countries, wood is the most reliable source of fuel therefore, people will destroy trees for that purpose. The incessant fuel scarcity has increased the dependence of most people on firewood as a source of fuel thereby increasing the pressure on the forests.

\section{Consequences Of Deforestation}

These are many and varied and also include the following (NEST, 1999; Taylor, 1983; Cane et al, 1980; Akachukwu, 2007; FAO, 2004; UNEP-WCMC, 2004; Wikipedia, 2007)

i. Food shortage and starvation

ii. Global warming

iii. Acid rain

iv. Desertification

v. Fuelwood scarcity 
vi. Erosion

5.1 Food Shortage And Starvation: With the destruction of forests, all foods derived from the forest will be reduced leading to starvation. Also, the entire world depends on a few countries in Western Europe and America for surplus supply of food, if there is bad climatic condition for some years due to deforestation, then starvation will increase.

5.2 Global Warming: (Greenhouse Effect): This is as a result of increase in the amount of carbon dioxide $\left(\mathrm{CO}_{2}\right)$ etc in the atmosphere due to the use of fossil fuel which ultimately increases the world's temperature. Consequently, ice could melt at the Polar Regions leading to floods. Other greenhouse gases include methane, nitrous oxide, Ozone and chlorofluorocarbons.

5.3 Acid Rain: This occurs mainly in industrialized areas where forests are been destroyed and industries established. The acid rain speeds up the weathering of buildings and is also chemically injurious to plants and animals. With gas flaring in the Niger Delta, Cross River State is prone to acid rain.

5.4 Desertification: With the removal of trees, the desert condition is encouraged since there is reduction of rainfall. The Sahara desert is encroaching southwards in Nigeria ; therefore, the northern part of the state is vulnerable.

5.5 Fuelwood Scarcity: The distances covered by fuelwood collectors increases yearly because adequate replanting measures are not put in place. Man-hours are lost and women and children are forced to trek long distance thereby leading to health problems.

5.6 Erosion: With the removal of tree species, the top soil which is most fertile is exposed to water and wind erosion leading to poor crop yield and starvation. At present, there are so many erosion sites in the state especially within the state capital.

5.7 Water Scarcity: Trees provide a cover thereby preventing streams from drying up especially in the dry seasons. With deforestation, most streams and rivers will dry up thereby leading to increase in water borne diseases.

\section{Problems Associated With Combating Deforestation}

Environmental problems are never localized, as problems caused in one part of the world can adversely affect the other part. Therefore, all hands must be on deck to combat the problems which include (Middleton, 1991; Carty, 1992; Came et al, 1980; Aderounmu et al, 1992; Akachukwu, 2007; FAO 2004; UNEP, 2004; Wikipedia, 2007):

i. Several opposing demands on trees

ii. North-South relationship

iii. Poverty

iv. Ignorance

v. Uses of loans by governments and NGOs

vi. Long period of maturity Insufficient care for planted seedlings

vii. Lack of substitute for trees.

\subsection{Several Opposing Demands on Trees:}

An agreement on a unified approach to forest protection at any level whether global, national or within the state or community is stalled by several conflicting demands on trees. For instance, some community members may want the forest to be untouched to permit their traditional ways of life (Including Masquerade shrines and Age-group Initiation Grounds) while others within the same community view the forest as an index of underdevelopment which should therefore be removed. Others believe that the forest will never, finish,since it re-grows, therefore it should be cut down for agriculture and the trees sawn, some burnt without any replanting measures. Environmentalists want the forests to be undisturbed without providing adequate means of livelihood to other forest users while agriculturalists, miners, road builders, loggers, town planners and ranchers want the trees cut and without any commensurate replanting measures.

6.2 North-South Relationship: The developed nations of the north which produce a lot of toxic wastes and greenhouse gases want the tropical forests kept as the purifying lungs of the world and garden of biodiversity. However, these developed nations have refused to make any major financial investment in forest preservation to the developing countries of the South. A case in point is the vehement refusal of the Directorate for International Development (DFID) to extend their assistance to plantation development in Cross River State, when they were assisting the Forestry Commission of the state.

6.3 Poverty: Poor people all over the world will always encroach upon the forest. They view the forest as a God-given wealth which will never be depleted. With retrenchment and compulsory retirement of workers by government as well as the inability of government to provide basic needs for its citizens, the pressure on forests 
increases daily. For instance, the incessant scarcity and high cost of kerosene and gas has made many people to depend on fuel wood for cooking, leading to increased forest destruction.

6.4 Ignorance: Some people are not aware that, the forest and its resources can easily be depleted if not sustainably managed. They are oblivious of the several benefits derived from the forests, therefore, they do not care about what happens to the forests and in most cases they help in the destruction of the forests.

6.5 Uses of Loans by Government and other Non-Governmental Organizations: There are cases where international donors make loans available for development projects, leading to government opening up the forest region and rich people/companies coming to buy wood without due consideration for the environmental costs. In some cases, the money may not even get to the government agency in charge of forest operations. That is, there is possibility of mis-appropriation by government and non-governmental agencies.

6.6 Long Period of Maturity: Most tropical trees take about seventy (70) years to reach maturity and there is hardly any bank that will lend money for a project that takes about 70 years to mature.

6.7 Insufficient Care for Planted Seedlings: Millions of seedlings have been planted in Africa, Asia and America only to perish as a result of lack of proper care. In Nigeria, after the annual "ritual" of National tree planting by high Government Officials, there is no provision for maintenance in most cases leading to the death of these plants. In other cases, the plants are trampled to death by human beings and cattle or cut down for firewood long before heir prime or left to compete with weeds.

6.8 Lack of Substitute for Trees: Environmentalists preach against deforestation without necessarily providing substitutes. It should be noted that poverty, hunger and ignorance could drive a person to clear the forests to plant his crops; lack or high cost of kerosene and gas will lead to the need to use wood and charcoal for fuel. Construction and industrialization must be embarked upon with wood as a major component. Therefore, the environmentalists and foresters face an uphill task of convincing the masses to conserve trees.

\section{Recommendations}

Having highlighted the importance of forests and the consequences of deforestation, the following recommendations are imperative.

i. Adequate funds should be provided by government, individuals and non-governmental organizations with the view to raising nurseries and plantations. Also, more forestry personnel should be employed and motivated to police the forests from indiscriminate felling of trees. Efforts should be concentrated on planting indigenous species in order to boost biodiversity; however, exotics could be used in degraded areas as a result of their fast growth.

ii. Research should be carried out by foresters to develop fast growing trees as well as those resistant to fires and pathogenic attacks.

iii. Developed countries should sponsor reforestation Programmes in third world countries whole heartedly. Cross River State which has a high percentage of biodiversity should be well considered.

iv. Serious awareness campaign should be created by the government and environmentalists on the important role played by the forest and the current National Tree Planting Campaign is a mere ritual as well as a radio and television propaganda should be redesigned. The negative impact of deforestation should be made known to the masses.

v. A cheap and readily available substitute for fuel wood should be sought immediately. Already, there are kerosene and gas alternatives which unfortunately are neither cheap nor readily available thereby rendering trees vulnerable to destruction in Cross River State.

vi. Environmental laws should be revised and fully implemented to carry severe jail terms and fines. At present, very few if any defaulters had ever been prosecuted under existing laws.

vii. Efforts should be geared towards the domestication of some wild animals which are hunted for "bush meat" in order to reduce bush burning and hunting.

viii. Intensive agriculture where tree branches and animal droppings are used to fertilize the soil and several species of crops are planted on the same plot should be encouraged. This will reduce the technique of shifting cultivation and multiple use of the land will be enhanced, thereby, leading to forest conservation.

ix. Bush burning should be discouraged and where it is unavoidable, then fire tracing should be employed to prevent the fire from spreading beyond the proposed area.

\section{Conclusion}

Cross River State is naturally endowed with a lot of forest resources rich in biodiversity. The importance as well as threats to these forests has been highlighted. Therefore, all hands should be on deck to ensure that the rich biodiversity of the state is conserved, especially when one considers the fact that, environmental problems are not localized. That is, the consequences of an environmental problem can be felt in an area several thousand kilometres from the source. 
It is estimated that, about 200 million hectares of new trees must be planted this decade at a tremendous cost of $\$ 100$ billion in order to meet the needs of developing countries. This type of programme will involve large scale reforestation projects as well as social forestry, that is, planting of trees by grassroots communities and individuals for their own use.

Most forest destruction in developing countries are caused by poor people who are denied access to land and have no alternative, except to clear land for existence, without an alternatives people will always cut down even the last trees, around them. Accordingly, the rich, government, and non-governmental organizations should provide the poor with satisfactory alternative to unsustainable forest exploitation.

\section{References}

[1]. Abang, S.O and Omolaubi, D.A. (1994); Marketing Margins in Non-Timber forest products trade in Cross River State of Nigeria Working Paper No. 12 Prepared for the Cross River State Forestry Project (ODA Assisted)

[2]. Aderounmu, A; Akarue, J; Ette. M (1992). A forest was here. Newswatch Communications Ltd. Lagos.

[3]. Akachukwu, AC (2007). Disappearing forest, the consequence and challenges of sustainable Development in Nigeria in Proceedings of $31^{\text {st }}$ Annual Conference of the forestry Association of Nigeria held in Markurdi, Benue state, Nigeria. $20^{\text {th }}-25^{\text {th }}$ November, 2006 , $\operatorname{pr} 48-61$

[4]. Akintoye ., OA, Bisong, , F.E, Utang., P.B and Andrew-Essien .,E. (2013) Impact of Logging on Non-Logged Species in the Moist Forest Region of South Eastern Nigeria ,Journal of Environment and Earth Science, Vol. 3, No.3, 2013

[5]. Alexander, D.M. and Effa, A. O (1994): The Non Timber Forest products Report: The Preliminary NTFP survey of Cross River State. Prepared for Cross River State Forestry Project (ODA Assisted).

[6]. Bisong FE and Mfon P (2008) Effect of Logging on Forest Regeneration in South-Eastern Nigeria, Environmental Research Journal 2 (3): $115-121$

[7]. Came, B., Jensen, H., Lord, M., Reissis A ., Rohter, L., (1980) Where have all the Forests gone? , Newsweek Magazine, No.4 ; Newsweek Inc. ; New York

[8]. Carty, W.P. (1992). The Dying Forest, Newswatch Magazine. Vol. 16, No. 24 Newswatch Communications Ltd , Lagos.

[9]. Ettah, A.E. and Ogar, G.E. (1994); An Assessment of Cross River State Forest Plantations. Working paper No.5 prepared for Cross River state Forestry project (ODA Assisted).

[10]. FAO (2004). Forest Reserve situation Assessment of Nigeria FAO. Rome, Italy (http://www/fao.org/docrep/00/ab578e/ab578e02) , Assessed : 1-12-2005

[11]. Forestry Development Department (1994): A strategy for Sustainable development, Conservation and Management of the Forest of Cross River State. Unpublished.

[12]. Mfon, P (1996); The Environmental Impact of Deforestation Department of Geography, University of Calabar , Calabar , Nigeria, Unpublished.

[13]. Mfon, P. (1997): Report of the visit of PGDEE students of 1995/96 session to stubbs Creek Forest Reserve in Ibeno and Eket Local Government area of Akwa Ibom state.Department of Geography, University of Calabar , Nigeria

[14]. Middlelon, N (1991); Atlas of World Issues. Oxford University Press (OUP). London

[15]. Moses E. B. (1986); Distribution, Ecology and Fisheries potentials of Nigerian Wetlands. Proceedings of the man and the Biosphere state of knowledge workshop on Nigerian wetlands Held at port Harcourt, Rivers state Emni Press Samonda, Ibadan, Nigeria.

[16]. Nigerian Environmental study Group (NEST) (1991); Nigerian Threatened Environment: A national profile Intec Printers Ltd Ibadan.

[17]. Nwoboshi,L C (1982): Tropical Silviculture:Principles and Techniques.Ibadan University Press, Ibadan.

[18]. Okpiliya F.I, Udida A.A. and Oka, P (2013) Effect of Timber Resource Processing on the Edibe-Edibe Creek in Calabar South Local Government Area of Cross River State, Nigeria, International Journal of Physical and Human Geography, Vol., No.1, March 2013, pp.10-17

[19]. Richards P.W. (1952): Tropical Rain Forest. An Ecological study, Cambridge university Pres, London.

[20]. Strahler, A. H. Strahler A.N (1977): Geography and Man's Environment. John Wiley and Sons New York, Toronto

[21]. Taylor C.T (1983); What is wrong with our weather? The Plain Truth Magazine. Vol. 48 No.4 Ambassador Press; England.

[22]. Ukata, S., U, Akintoye, O.A ., Ekeh, J.E and Ogar ., A.M (2013) An Appraisal of Primate Conservation Programme by Pandrillus (Non-Governmental Oranization) in Afi Mountain Sanctuary, Buanchor, Boki Local Government Area , Cross River State, Nigeria, International Journal of Innovative Environmental Studies Research 1 (3):77-82

[23]. United Nations Environment Programme - World Conservation Monitoring centre (UNEP - WCRC) (2004). Protected trees, plant and Animal biodiversity. World database on protected areas. 